\title{
Profile of Iron Overload in Sickle Cell Syndrome Patients from Eastern India - Correlation with Common Parameters
}

\author{
Prosanto Kumar Chowdhury ${ }^{1 *}$, Jena $\mathrm{RK}^{2}$, Dhritidipa Chowdhury ${ }^{3}$, Manas Saha ${ }^{4}$ and R Sinha ${ }^{5}$ \\ ${ }^{1}$ Consultant, Institute of Child Health, India \\ ${ }^{2} \mathrm{HOD}$, SCB Medical College, India \\ ${ }^{3}$ Medical Officer, Indian Railways, India \\ ${ }^{4}$ Visiting Consultant, Peerless Hospital and B. K. Roy Research Centre, India \\ ${ }^{5}$ Associate Professor, Institute of Child Health, India
}

Submission: March 03, 2017; Published: April 06, 2017

*Corresponding author: Prosanto Kumar Chowdury, Consultant, Institute of Child Health, India, Email: prosanto.chowdhury@cordlifeindia.com

\begin{abstract}
Introduction: Eastern India -the melting pot of different heterozygous Sickle cell syndrome. Mostly NTDT, we wanted to study the pattern of iron overload in this heterogeneous yet homogenous group of patients. As there is no such study from this part of the world, it would reveal the true state of iron overload, appropriate test/s and chelation requirement.
\end{abstract}

Methodology: 152 subjects of Sickle cell syndromes (SS, SB, SE, SD and S Lepore), 5 to 60 years, both sexes, were subjects to crosssectional study, transfusion requirement was calculated retrospectively. Biochemical parameters - hs-CRP and Ferritin and LIC by MRI and correlated to TIL. Chelation requirement was determined.

Observation: All subjects had high hs-CRP $(2.67 \pm 2,21)$ and Ferritin $(5231.8 \pm 1071.8)$, highest in HbSD Disease and lowest in SB. LIC by MRI R2* was $5.14 \pm 3.67 \mathrm{mg} / \mathrm{G}$ DLT, highest in S Lepore and SS. Hepatic Fibroscan revealed $13 \pm 5 \mathrm{kPa}$ and Grade $3-4$ fibrosis, mainly in Hb SS patients.

Discussion: Iron overload was noted from second decade. Ferritin gives false high results, when compared to LIC. Even in the absence of significant iron overload, hepatic fibrosis was noted.

Conclusion: Iron overload requiring chelation exists in Sickle Syndrome. Iron overload as estimated by Ferritin is on the higher side, CRP level can be used to exclude inflammatory state. LIC by MRI is the best. Subjects with high CRP and ferritin, have hepatic fibrosis, LIC though normal, regular chelation therapy to control LPI, NTBI and other Oxygen derived free radicals may help.

Keywords: Sickle cell syndrome; Fibrosis; Thalassemia Sickle Cell Syndrome, Fibrosis, iron over load

\section{Introduction}

Sickle cell disease accounts for the highest percentage of single gene disorders in the world. India is no exception. Due to population migration and cross marriages Sickle Cell Syndromes has become very common in the eastern part of India, where it was virtually unknown. In 2007, after R Balgir's paper was published, the actual magnanimity of the problem was realized [1]. In the introduction, he wrote "India is a great and vast country with diverse and multiple castes, ethnic groups, religions, occupations, economic strata, languages, socio-cultural traditions, genetic heritages and life-styles and practices. Moreover, this country has absorbed in so many racial, religious, socio-cultural, linguistic and genetic elements that have given rise to amalgamation and conglomeration of all the constituent features, representing the cohesive unity in diversity in the true sense."The highest prevalence has been recorded in the state of Orissa (1-44.4\%), followed by Madhya Pradesh (140.0\%; including Chhattisgarh), Tamil Nadu (1-40.0\%), Andhra Pradesh (1-35.7\%), Assam (1-35.5\%), Maharashtra (0.8-35.0\%), Gujarat (1-31.4\%), Kerala (1-30.0\%), Uttar Pradesh (1.5-18.5\%), Karnataka (1-8.0\%), Rajasthan (1-5.7\%), West Bengal (1-1.7\%), and Bihar (0.8\%; including Jharkhand) in the decreasing order $[2,3]$. 


\section{Open Access Blood Research \& Transfusion Journal}

Prospective studies carried out in Orissa have revealed statistically significant differences in hematological indices between sickle cell trait and sickle cell disease, sickle cell- $\beta++$ thalassemia and sickle cell- $\beta+-$ thalassemia; between sickle cell disease and sickle cell- $\beta++$ thalassemia and sickle cell- $\beta+$ -thalassemia and between sickle cell- $\beta++$ thalassemia and sickle cell- $\beta+$ - thalassemia were observed with variable symptomatology and clinical manifestations [4,5]. Genetic heterogeneity of sickle cell- $\beta$-thalassemia is noticed in India. Both mild (African) and severe (Mediterranean) forms of sickle cell- $\beta$-thalassemia (i.e., $\beta++$ thalassemia and $\beta+$ thalassemia or $\beta$ $o$-thalassemia) are encountered, suggesting the gene flow from the East Mediterranean, Asian Gulf, sub-Sahara and East Africa reflecting historical events and gene migrations in the region, having implications in community health genetics in India [6,7].

Genetic diversity and heterogeneity with respect to the genetic markers indicated not only inter-tribal admixture but also the diffusion with other racial groups of India. This may be due to continuous pressures of gene diffusion from different waves of people penetrating their territory and habitats in Orissa in the course of invasions and migrations from the NorthWestern (Indo-Aryan) and North-Eastern (Mongoloid) parts of India during the ancient and historical time $[8,9]$.

It becomes amply evident from the introduction given above, that due to population migration, population drift and inter ethnic marriages, gene diffusion had occurred, which has led to emergence of double heterozygous states, adding to the already existing huge homozygous sickle cell disease burden.

The different types of double heterozygous states, like $\mathrm{Hb} \mathrm{S/}$ $\beta o, \mathrm{Hb} \mathrm{S} / \beta+, \mathrm{Hb} \mathrm{S} / \beta++, \mathrm{Hb} \mathrm{S} / \mathrm{E}, \mathrm{Hb} \mathrm{S} / \mathrm{D}, \mathrm{Hb}$ S/Lepore and $\mathrm{Hb}$ $S / C$ have been identified in the Eastern region of India. Here the primary disease which is precipitated by the hemoglobin $S$, is modified to varying degree by the other mutations, which may render, the disease state more or less severe, depending on the secondary mutation.

We have scanned most of the articles available on the net and in hard copies. It has been revealed that, though it has been realized that pathophysiology and morbidity pattern are different for these different double heterozygous states, but it has not been documented how to differentially treat and manage each case, such that a patient is optimally managed, to provide a socially and economically productive life. In this article, we would study the effect of the secondary mutation on the primary disease of hemoglobin $\mathrm{S}$, on the iron overload status of the patient and it's implications.

\section{Aims and Objectives}

The aim of the study was to

a. To study and prove that iron overload indeed exists in Sickle Cell Syndrome patients.

b. To study the pattern of iron overload in Sickle Cell Syndrome patients. c. To estimate the picture of the conventional iron overload parameter like Ferritin in serum in such patients.

d. Ferritin being a parameter of inflammation, should also be influenced by the chronic inflammatory state of individuals suffering from Sickle Cell Syndrome, so its relation with the other easily available hs CRP was studied, in parallel to it. To check if serum ferritin and hs CRP levels could be correlated.

e. Actual level of hepatic siderosis would be estimated by Hepatic R2* estimation by MRI.

f. Statistical relation of conventional iron overload parameters would be sought with parameters of inflammation, i.e., Serum ferritin and hs CRP and the true parameter of iron overload, independent of inflammatory state would be established.

g. Pattern of hepatic fibrosis would be mapped and its relation to hepatic siderosis would be sought.

h. Depending on the pattern of hepatic siderosis, scope of chelation therapy, in Sickle cell syndrome patients would be established and it's beneficial effect on hepatic fibrosis if any would be established.

\section{Materials and Methods}

152 patients, all suffering from double heterozygous hemoglobin S related disorders, were selected for the study (Figure 1).

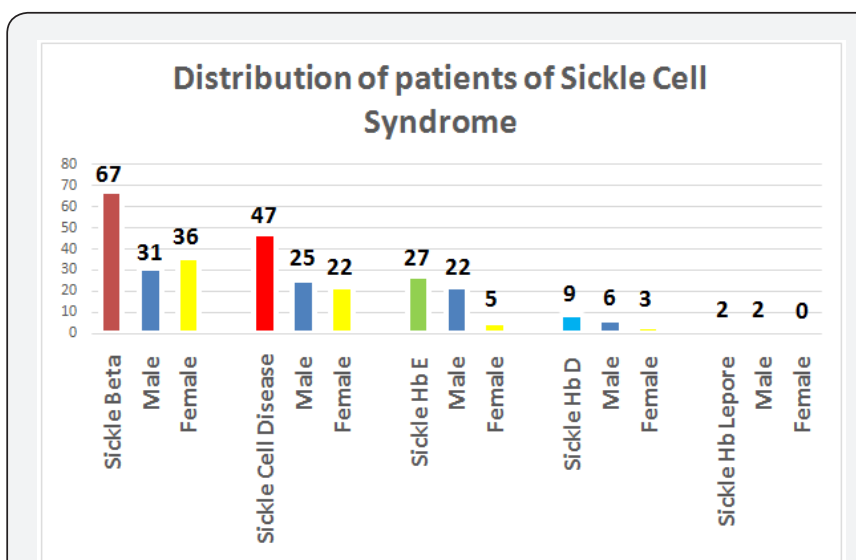

Figure 1: Distribution of patients of Sickle Cell Syndrome.

Sickle Cell Disease: 47 subjects, 25 male and 22 female

Sickle Beta Thalassemia: 67 subjects, 31 male and 36 female

Sickle Hemoglobin E Disease: 27 subjects, 22 male and 5 female

Sickle Hemoglobin D Disease: 9 subjects, 6 male and 3 female Sickle Hemoglobin Hb Lepore Disease: 2 subjects, both male.

This was conducted as a prospective and longitudinal study from March 2014 - January 2017. The study population consisted of patients whose age limit was more than 5 to 60 years. All the 
subjects had to test negative for Hepatitis B, C and HIV by Nucleic Acid Test. The subjects were tested for Liver function tests, Serum ferritin and highly sensitive C- Reactive Protein (hs-CRP), every four monthly, as biochemical parameters (Figure 2).

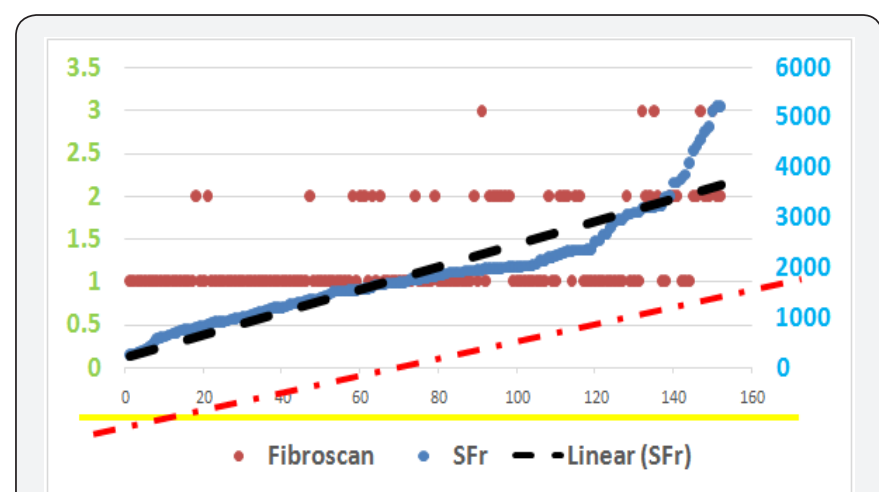

Figure 2: Relation between Serum Ferritin and hs CRP.

Hepatic Iron Overload was estimated, in accordance to the R2* technique by Magnetic Resonance Imaging and hepatic fibro scan was done by standard elastography technique, on yearly basis. The data was collected and analyzed statistically. Any relation between parameters of liver function, parameters of inflammation and iron overload and its relation to hepatic fibrosis was sought, through statistical correlation.

\section{Results}

Level of serum Ferritin was $1925.82 \pm 1071.82 \mathrm{ng} / \mathrm{dl}$, the minimum being 234ng/dl and the maximum $5231 \mathrm{ng} / \mathrm{dl}$. The lowest level of serum ferritin was recorded in Sickle hemoglobin E patient and the highest in $\mathrm{Hb} \mathrm{S}$ Beta0 thalassemia patient.

Level of hs CRP was $2.67 \pm 2.21$, the minimum being 0.05 and the maximum 12. The lowest level of hs CRP was recorded in Sickle hemoglobin E patient and the highest in Sickle Hemoglobin D patient. Hepatic Liver Iron Concentration R2* by MRI was $5.14 \pm 3.67 \mathrm{mg} / \mathrm{g}$ DLT, the minimum being $1.0 \mathrm{mg} / \mathrm{g}$ DLT and the maximum $15.6 \mathrm{mg} / \mathrm{g}$ DLT. The lowest level of serum ferritin was recorded in Sickle hemoglobin E patient and the highest in $\mathrm{Hb} \mathrm{S}$ Beta0 thalassemia patient.

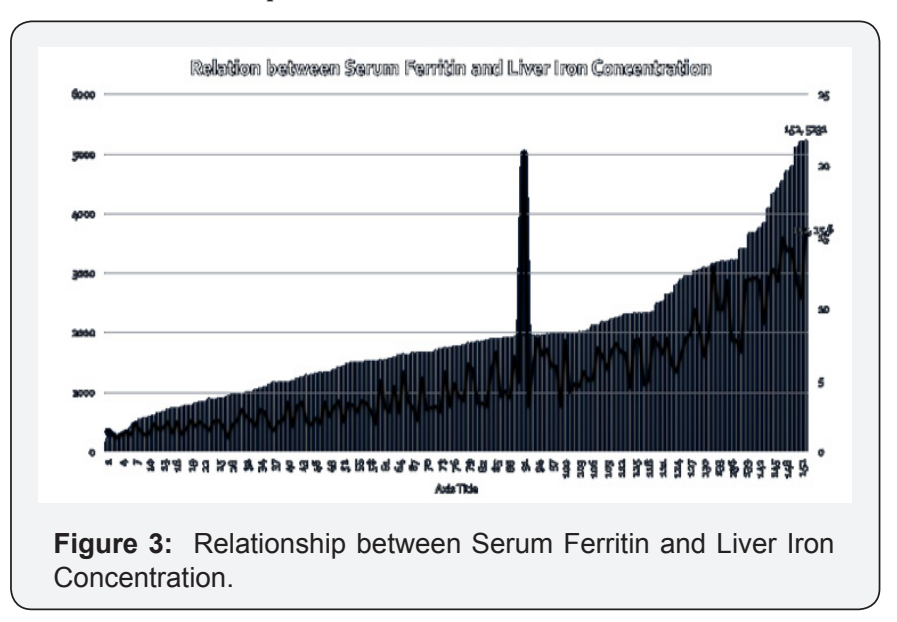

Hepatic fibro scan score was $1.3 \pm 0.52$, the maximum being 3 and the minimum 1 . The maximum level was recorded in Homozygous Sickle Cell disease and the minimum level was recorded in Sickle Hemoglobin E disease (Figure 3).

Statistical correlation revealed a correlation of 0.09 between Serum Ferritin and hs- CRP, but the Serum ferritin and LIC revealed 0.87 and Serum ferritin and fibro scan revealed 0.48 . The correlation between CRP and fibro scan was -0.03 and between hs CRP and LIC was 0.02 . The correlation between fibro scan and LIC was 0.85 .

\section{Discussion}

This study has revealed that there is semi-linear correlation between serum ferritin and hs CRP. There is no statistical correlation between hs CRP and liver iron concentration. There is direct correlation between serum ferritin and liver iron concentration amongst all types of patients of sickle cell syndromes, when the level of serum ferritin is less than 300ng/ $\mathrm{dl}$ and liver iron concentration less than $2 \mathrm{mg} / \mathrm{g}$ DLT. There is loss of correlation between liver iron concentration and serum ferritin from $>300$ to $3000 \mathrm{ng} / \mathrm{dl}$ and liver iron concentration level of $>2 \mathrm{mg} / \mathrm{g}$ DLT to $5 \mathrm{mg} / \mathrm{g}$ DLT. Correlation is re-established at serum ferritin level above $3000 \mathrm{ng} / \mathrm{dl}$ of serum ferritin and $>5 \mathrm{mg} / \mathrm{g}$ DLT.

The level of hs CRP and Serum Ferritin did not show any statistical correlation with fibro scan score, but the fibro scan Score correlated with the liver iron concentration.

The higher the liver iron concentration the higher is the fibro scan score, but fibro scan scores can be higher in situations where the LIC is within normal limits, but the serum ferritin and the hs CRP may be high (Figure 4).

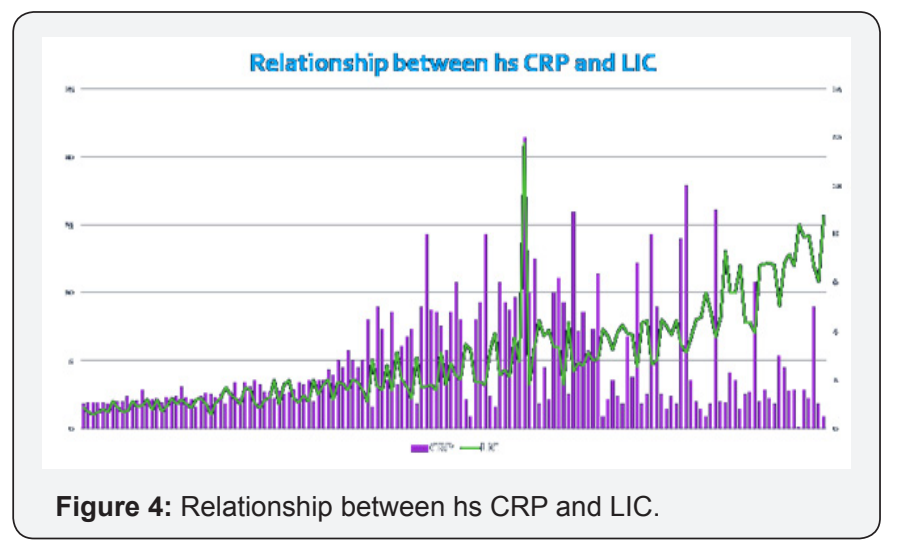

\section{Conclusion}

It can be concluded that Sickle cell syndrome patients suffer from iron overload also like any other haemoglobinopathies and thalassaemias, as evidenced by hepatic iron overload of more than $7 \mathrm{mg} / \mathrm{g}$ DLT.

As all types of double heterozygous states related to hemoglobin S containing disorders, there is a perpetual chronic 
inflammatory state, which elevates the level of serum ferritin. Serum ferritin level is falsely elevated due to the inflammation which is proved by the high level of hs CRP, which is also elevated. So the level of Ferritin in the serum is actually a bad indicator of iron overload in subjects of Sickle Cell Syndrome, it over estimates iron load. Better indicator of iron overload is hepatic iron concentration measurement by MRI. If Serum Ferritin is to be used as an indicator of iron overload it should be correlated against the level of hs CRP, if hs CRP is within normal limits then the trend of ferritin may be accepted as a parameter of iron overload in these subjects.

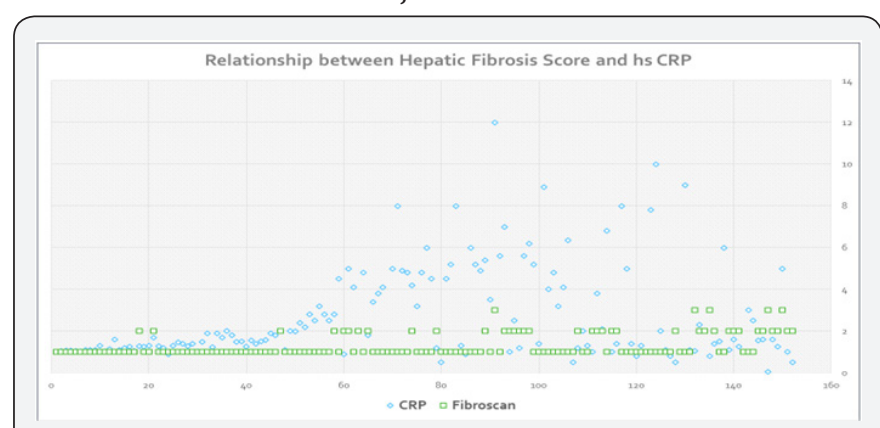

Figure 5: Relationship between Hepatic Fibrosis score and CRP.

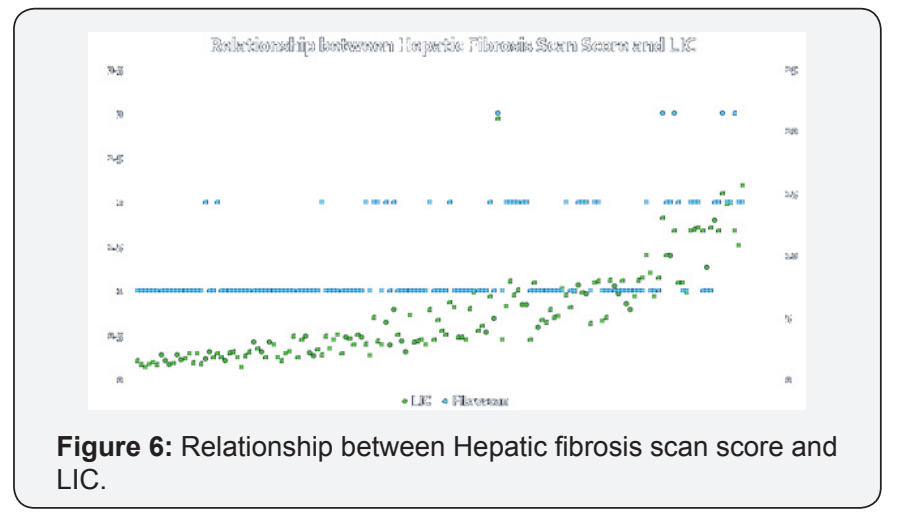

It has also been observed that most subjects suffering from Sickle Cell syndrome have hepatic fibrosis, though there is not enough iron in the liver as evidenced by MRI (Figure 5). There is evidence of comparable level of iron in the liver of thalassaemic subjects, but absence of fibrosis. It has also been observed that hepatic fibrosis has been observed in such subjects even in the absence of significant iron overload in the liver. SO, it is possible that the oxygen derived free radicals, labile pool iron and non transferrin bound iron may be responsible in the perpetual inflammatory state. It has been observed that very low dose of Deferasirox of $0.5 \mathrm{mg} / \mathrm{kg} /$ day used in non hepatic iron overload subject was able to halt the progress of the fibrosis (Figure 6).

Iron chelation therapy, if at all, is beneficial to the subjects can be decided in a well controlled study, secondly if iron chelation therapy is at all required or the parameters of initiating the chelating agents and the indications of discontinuing it requires to be validated and put in the form of specific guidelines.

\section{References}

1. Balgir R (2007) Epidemiology, Population Health Genetics and Phenotypic Diversity of Sickle Cell Disease in India. The Internet Journal of Biological Anthropology 1(2).

2. Balgir RS, Sharma SK (1988) Distribution of sickle cell hemoglobin in India. Indian J Hemat 6: 1-14.

3. The prevalence of sickle cell hemoglobinopathy in India (1996) In: Madhava Menon T, et al. (Eds.). Encyclopedia of Dravidian Tribes. Trivendrum: The International School of Dravidian Linguistics, India 1: 21-29.

4. Balgir RS (1996) Genetic epidemiology of the three predominant abnormal hemoglobins in India. J Assocn Phys India 44(1): 25-28.

5. Balgir RS (2004) Health care strategies, genetic load, and prevention of hemoglobinopathies in tribal communities in India. South Asian Anthropologist 4:189-198.

6. Balgir RS (2005) Spectrum of hemoglobinopathies in the state of Orissa, India: a ten years cohort study. J Assocn Phys India 53: 10211026.

7. Balgir RS (2006) Scenario of hemoglobin variants in Central East coast of India. Curr Sci 90(12): 1651-1657.

8. Balgir RS (2007) Aberrant heterosis in hemoglobinopathies with special reference to - thalassemia and structurally abnormal hemoglobins E and S in Orissa, India. J ClinDiagn Res 1(3): 122-130.

9. Balgir RS (2008) Phenotypic diversity of congenital sickle cell disorders and their impact on community health genetics in India. International Conference on Medical \& Community Genetics.

\section{Your next submission with Juniper Publishers will reach you the below assets}

- Quality Editorial service

- Swift Peer Review

- Reprints availability

- E-prints Service

- Manuscript Podcast for convenient understanding

- Global attainment for your research

- Manuscript accessibility in different formats

( Pdf, E-pub, Full Text, Audio)

- Unceasing customer service

Track the below URL for one-step submission https://juniperpublishers.com/online-submission.php 